\title{
University Libraries in Turkey
}

\author{
Bülent Karasözen \\ Middle East technical University \\ Doğan Atılgan \\ Ankara University
}

\begin{abstract}
In this article a short review of the history of Turkish university libraries is given by explaining the problems and issues. Recent developments in library cooperation as consortia building are also described.
\end{abstract}

The history of libraries in Turkey dates back to the fifteenth century. During the Ottoman times, the first religious college (medrese) libraries appeared at the end of sixteenth century. At the beginning of seventeenth century in major cities, mosques and colleges had libraries with small sized collections. This library system had dominated until the eighteenth century when the reform movement in the Ottoman Empire started. The first university libraries of Western type with printed books were established in the Imperial Naval Engineering College in 1793 and Imperial Military Engineering College in 1795 in Istanbul. In these libraries the textbooks were in French, which at that time was the dominating language of the Ottoman elite. These two institutions represent the first diversion from the traditional education of the "medreses", and were later merged to form the roots of today's Istanbul Technical University. This development continued until the foundation of Darülfunun((House of Sciences) in Istanbul in 1863, the first university of western type. Darülfunun had a library which was open to students and to the public. In 1912 several faculties were set up in Dafülfunun, which gained scientific and administrative autonomy after the establishment of the Turkish Republic in 1924. The naval and military engineering colleges were merged in 1909 as the Higher School of Engineers, where engineering and architecture faculties were established and civilians were admitted to these colleges. During the university reform period in 1933 Darülfunun was converted to Istanbul University, with a big library. In 1931, the government invited Professor Albert Malche of the University of Geneva to prepare a report on Turkish university reform. During the university reformation period following Malche's report in 1944, the Higher School of Engineers was also reorganized to become Istanbul Technical University.

After the announcement of the university law in 1946, the government started to establish libraries also in other cities. In his report, Albert Malche underlines the key role of librarians in the university and describes the Turkish libraries with scattered, poor collections, insufficient funding, lack of cooperation, restricted access of public to the libraries, limited opening hours and low salaries of librarians. Even today as Turkey makes big step towards western civilization, many of the problems and issues of libraries discussed in this report persist still. A detailed overview of the Ottoman library system and the libraries in the modern Turkish Republic is given in (Içimsoy 2008). It was concluded in this article that many of the above mentioned problems had existed in the Ottoman library system. In the fifties we see the appearance of German library system with faculty, departmental and institutes libraries in Ankara, Istanbul University and Istanbul Technical University. In the report prepared for the Ministry of Education by Dr. 
Lawrence S. Thompson in 1952, it was criticized that Turkish universities don't have any central libraries. The development of modern university libraries started when the Middle East Technical University (METU) was founded in 1956 in Ankara. METU Library was the first library that was based on American campus system, thereby providing central library services for all students and faculty (Tonta 2001). Until 1960 the university libraries were controlled by the Ministry of Education. After the new constitutional, the universities gained their autonomy and librarians got the status of "expert" administrative staffing the universities. In these years in a number of universities Department of Librarianship and Archival Studies were established. After the military coup in 1980, the Council of Higher Education (YOK) was established in 1982 to bring the universities under the government control. The universities lost their autonomy. Within YOK, a Documentation Centre was established to supply universities with research articles and related documents by providing photocopying services to the universities. The Centre subscribed also some databases, where the academics could make searches. The aim of establishing this Centre was to encourage the universities to spend their budgets to the acquisition of books and other materials. During this time big university libraries like METU, Hacettepe and Istanbul Technical University had to cancel many of their journal subscription due to budget cuts by the Higher Education Council. In the nineties, due to the increase of journal prices worldwide and a financial crisis in Turkey, the Documentation Centre of YOK had to reduce journal subscription from about 10.000 to 3.000. In the mid-nineties a protocol was signed between Higher Education Council and TUBITAK(Turkish Scientific and Technical Research Council) for transferring the Documentation Centre to ULAKLBIM(National Academic Data Processing Centre). But the problems still continued within the ULAKBIM. One of the main weaknesses of Turkish university libraries was the lack of nationwide interlibrary loan and document delivery system.

Currently in the Turkish higher education system there are 113 universities. Of these, 94 are state funded and 33 are private, so called foundation universities. 46 of these universities have been founded in the last ten years. The higher education institutions had about 1.7 million students and academic staff in the 2006-2007 academic years. The university population in 2006-2007 consisted of 55\% undergraduate, $31 \%$ vocational, $7 \%$ master and $2 \% \mathrm{PhD}$ students. The proportion of academic staff was $5 \%$ of the total university population. Although $27 \%$ of the universities are private universities, these have only $8 \%$ of the total university population. The FTE (full-time equivalent) of the universities varied from 1,000 to over 50,000. University library collections and budgets are rather limited. For instance, the total number of items held in all university libraries is around six million. The library collection expenditures varied in 2007 between $\$ 200,000$ and $\$ 3,000,000$. The proportion of library budgets to the university budgets range between $0.2 \%$ and $5 \%$, average being $0.6 \%$. The total amount of money allocated to all university libraries in 2007 was just about 35 million US dollars. There has been a big variety among libraries of developed and newly founded universities in terms of average expenditure per student. Because of low salaries the percentage of librarians working in the universities decreased in the last twenty years. Only one forth of the employees in the university libraries are librarians by profession. The average number of librarians per university is about six. There is again a big gap between the developed and developing universities in terms of library staff.

Under these diverse university structures and library resources, in 2001 nine libraries, initiated by METU, established ANKOS (Anatolian University Library Consortium) for licensing electronic journals. Within few years ANKOS has become one of the largest 
consortia in Europe. In 2007, ANKOS members had access to 35 major e-journal collections, e-references, bibliographic databases and e-books. The total number of databases times licensing libraries increased from 129 in 2001, to 968 in 2007, which correspond to $45 \%$ annual average growth rates. Similarly, the number of full text downloads increased from 1.4 million in 2001 to 11.5 million in 2007. The annual average growth rate of usage of e-journals with the consortium was about $47 \%$. All these developments were in accordance with the rapid increase of Turkish scientific publication since 1981. According to (Glaenzel 2008), Turkey belongs after China, with South Korea, Brazil and Taiwan to the most dynamic countries with an average annual growth rate $14 \%$ in the world share of scientific publications between the years 19972007 and the number of scientific publications reached 16.500 in 2007. The development of ANKOS was documented in (Karasözen 2004) and in (Karasözen 2007). ANKOS has created a national site license (TRNLS) and has developed related licensing principles in 2002 (Lindley 2003). All negotiations and contracts were based on the model license. Within ANKOS several working groups like licensing, user training, evaluation of usage statistics and open access were established. In addition to licensing of databases, ANKOS was actively involved in the open access movement in Turkey. A brochure was created to raise awareness for OA among the academics and librarians and an institutional repository hand book was prepared to help the librarians for establishing institutional repository in their universities. ANKOS is a member of ICOLC, SEL(Southern European Library Link), SPARC and COUNTER. Recently two international library conferences took place in Turkey: in 2003 annual IATUL conference was hosted by METU in Ankara, and in 2008 the LIBER annual meeting hosted by Koç University in Istanbul.

As a summary it can be concluded, that despite the lack of a national policy for university libraries, centralized structure of higher education, problems and issues described in this article, Turkish librarians try to meet the increasing demand of the researchers and students for scientific literature in the rapidly changing library environment.

\section{References}

İçimsoy, A. Oguz, Erünsal, E. İsmail: The Legacy of the Ottoman Library in the Libraries of the Turkish Republic. In: Libri, 58 (2008) S. 47-57.

Tonta, Yaşar :Collection development of electronic information resources in Turkish university libraries. In: Library Collections, Acquisitions, \& Technical Services 25 (2001) S. 291-298.

Glaenzel, Wolfgang. Turkey on the way to the European Union? On a scientific power rising next door. In: International Society for Scientometrics and Informetrics (ISSI) Newsletter (2008) 4 S. 10-17.

Karasözen, Bülent, Lindley, Jane Ann: The Impact of ANKOS: Consortium, Development in Turkey. In: The Journal of Academic Librarianship, 30 (2004) S. 402-409.

Karasözen, Bülent, Kaygusuz, Ayhan, Özen(Bati), Hacer, Patterns of e-journal use within the Anatolian University Library Consortium, Serials - 20, 37-42, 2007

Lindley, Jane Ann. The Turkish National Site License (TRNS. In: Serials 16 (2003) S. 187-190. 